Seckel, H. 1977: Höhenänderungen im grönländischen Inlandeis zwischen 1959 und 1968. Meddr Grønland 187(4), 58 pp.

Warren, C. R. 1991: Terminal environment, topographic control and fluctuations of West Greenland glaciers. Boreas 20 , $1-15$.

Weidick, A. 1968: Observation on some Holocene glacier fluctuations in West Greenland. Meddr Grønland 165(6), 202 pp. (also Bull. Grønlands geol. Unders. 78).

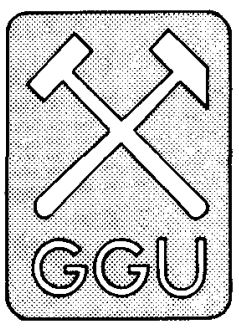

\title{
Economic mineral resources: activities in 1990
}

\author{
Hans Kristian Schønwandt
}

Weidick, A. 1991: Present-day expansion of the southern part of the Inland Ice. Rapp. Grønlands geol. Unders. 152, (this volume).

Zwally, H. J., Brenner, A. C., Major, J. A., Bindschadler, R. A. \& Marsh, J. G. 1989: Growth of Greenland ice sheet: measurement and interpretation. Science 246, 1587-1591.

A. W., Geological Survey of Greenland, Copenhagen.

The most exciting discovery in mineral exploration in Greenland in 1990 was announced by Platinova Resources Ltd. and Corona Corporation. A single packsack drill hole intersected a gold-platinum rich zone in the layered mafic Kap Edvard Holm complex of East Greenland (Fig. 1). The mineralised zone consists of an upper gold-rich section overlying a platinum-rich section. Gold values averaged $2.6 \mathrm{ppm}$ over $1.5 \mathrm{~m}$ while the bottom section of the hole yielded $3.4 \mathrm{ppm}$ platinum. Surface sampling indicates that the platinum mineralisation extends 1.5 to $2 \mathrm{~m}$ below the bottom of the drill hole. The mineralised zone occurs in a well-defined layered sequence which can be followed for more than $10 \mathrm{~km}$.

The Kap Edvard Holm complex is located $12 \mathrm{~km}$ south of the Skaergaard intrusion (Fig. 1) where the same joint venture partners completed a $12000 \mathrm{~m}$ drilling programme on an extensive gold-palladium mineralisation. The modes of occurrence of the two mineralised zones are similar. Both intrusions belong to the Tertiary magmatic province of East Greenland that stretches along the coast for more than $1000 \mathrm{~km}$ (Fig. 1). Goldbearing hydrothermal veins and anomalous gold values have previously been reported and are related to the felsic igneous activity of the province (Thomassen, 1990b). The province is also known for its porphyry molybdenum occurrences.

Although the present knowledge of the metallogenesis of the Tertiary tectono-magmatic province is fragmentary, the mineral discoveries indicate that the entire province is an interesting exploration target. The most recent general review of the province is given by Nielsen (1987).

\section{Greenland Mineralisation Data Bank}

The first stage in the processing of data for the Greenland Mineralisation Data Bank (GREENMIN), which is planned to include information on all known economic mineral localities, has concentrated on West and North-West Greenland. In 1990 information from major mineral localities between Thule and Nanortalik was processed (Fig. 2). Processing of data from smaller or less well investigated mineral occurrences has also been completed for the area between Nuuk/Godthåb and Maniitsoq/Sukkertoppen, and is nearly complete for the Disko Bugt and Fiskenæsset areas. General background information on the establishment and aim of the data bank is found in Schønwandt (1990).

Presentation of information from the data bank in the form of tabular reports will be of two types:

(1) Summary Reports, providing a regional review of mineralisation occurrences, with selected data;

(2) Standard Reports, presenting a complete record of data available for a specific mineral occurrence.

Summary Reports list condensed extracts of data and are in two parts: one contains information on sulphide, oxide and native element occurrences, the other deals with industrial minerals, silicates and gemstones. The two parts share a common layout with each locality being described by code number, name, geographical 


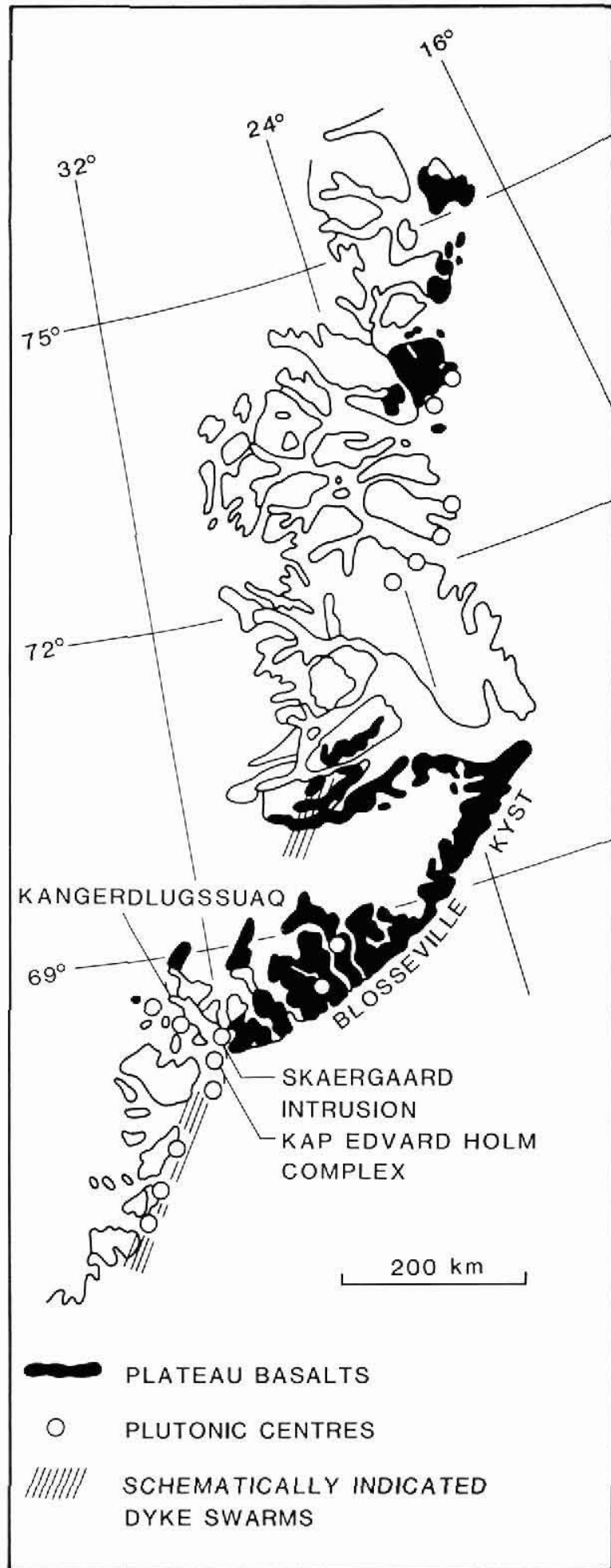

Fig. 1. Simplified geological map of the Tertiary tectono-magmatic province of East Greenland. coordinates, and specification of the commodities present, including deposit type and genetic type. The code number identifies the locality within the data bank, and should be used as a reference if a standard report is required.

In general, a genetic classification is ascribed to the mineral occurrences. As a rule this will reflect the opinions of the original sources for the information. but in some cases the data compiler may have considered a re-interpretation appropriate. Commodity presentation is different for the two parts. Sulphides, oxides and native elements are represented by metals and best assays if they attain values above a specified threshold. Industrial minerals, silicates and gemstones are represented by the commodity minerals.

Standard Reports deal with specific mineral occurrences. This type of report contains administrative information, geological data and a bibliography. The administrative-geological part mainly concerns concession data including present and/or previous concessionaires, period of the concession, area, confidentiality, rocks, stratigraphy, ore/gangue/alteration minerals, chemistry, resource estimates, structure and type of geological, geophysical, geochemical and technical investigations. The bibliographical part contains references to all published and unpublished sources used in data compilation of the mineralisation.

Mineral occurrence maps are being prepared for West Greenland. So far the Nuuk-Maniitsoq area is covered by five maps presenting localities with: gold-platinum group metals, copper-nickel, uranium-thorium-rare earth elements, molybdenum-wolfram-barium, and iron-chromium (Steenfelt et al., 1990). Supracrustal belts between Nuuk and Frederikshåb Isblink are covered by two maps presenting gold and copper-nickelzinc occurrences (Appel, 1990c). Gold mineral localities shown on the maps are assigned a code number which identifies the locality within the data bank (Appel, 1990b).

\section{Thematic Map Series}

The evaluation of mineral resources in Greenland relies on different types of geoscientific information. The combination of geophysical, geochemical, geological, and other data assembled by the Geological Survey of Greenland (GGU) provides a key to the understanding of regional geological provinces forming the framework within which mineral showings are found. A major activity has been to bring these data together into a form which facilitates their combined use. The main product of this work is a new GGU publication: the Thematic Map Series. It is hoped that the systematic 


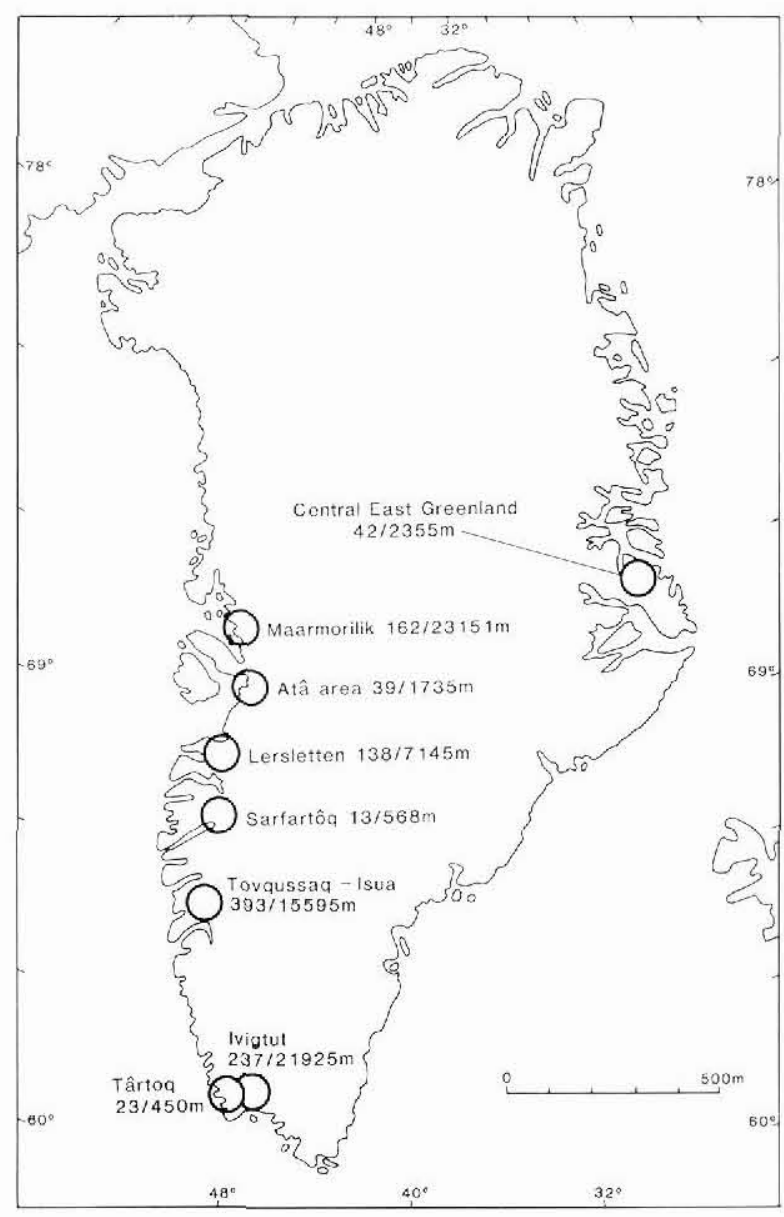

Fig. 2. Location in Greenland of drill cores now in the core library. The numbers, e.g. $23 / 450 \mathrm{~m}$, indicate number of drill holes and the total length in metres of core available from each site.

overview provided by these maps, together with other initiatives mentioned elsewhere in this paper, will make geoscientific data easily available to companies, institutions and individuals, further the search for suitable exploration targets, and thus help towards increased exploration activity in Greenland.

The Thematic Map Series concept was developed during 1990 and the first issue in the series was published in December 1990 (see below). The information for the maps is derived from GGU archives and data bases, company reports, scientific publications and other sources, including previously unpublished data. Publication of the maps is not conditional upon interpretation of the data, and other workers are thus encouraged to use the maps in any way they see fit, simultaneously with GGU's continued use of the data.

Compilation of the maps is computerised using com- mercially available software packages and in-house developed programmes. This involves digitisation of existing maps, reprocessing of existing digital data, and computer based production of new maps with a homogeneous appearance. The maps are plotted on a 300 dpi thermal transfer colour-plotter and are reproduced on demand as colour-photocopies of the original maps. This method allows for updating of the maps as new data become available, and other compilations derived from existing data.

The maps in any one issue of the Thematic Map Series are at a common scale and cover the same geographical area. The first issue covers a region of southern West Greenland between Nuuk and Maniitsoq. The next two issues, from South Greenland and Disko Bugt, are planned to be published in 1991 .

The first volume in the Thematic Map Series (Steenfelt et al., 1990) contains 57 maps:

- locality map, geological map (lithology) based on a revision of GGU's hitherto published map sheet,

- 3 magnetic anomaly maps based on GGU aeromagnetic surveys,

-2 gravity anomaly maps based on data from the gravity data base of Kort- og Matrikelstyrelsen (formerly Geodetic Institute), Denmark,

- 4 gamma-ray spectrometry maps based on GGU aeroradiometric surveys,

- 33 maps showing the geochemistry of stream sediments based on GGU sampling programmes,

- 3 maps showing the geochemistry of stream water based on GGU investigations,

- 5 maps showing panned heavy mineral concentrates based on GGU collections.

- 5 maps showing the occurrence of elements of economic interest based on data from the Greenland Mineralisation Data Bank, which contains both GGU and company data.

Additional maps from the same area are being considered for inclusion in later editions of the first issue based on new types of data, e.g. remote sensing, structural geology, or based on interpretation of combinations of the basic maps tabled above.

As a result of the production of the thematic maps, all basic data are brought into a digital form. The precise format of this depends on the type of data, which varies from geology, over grids of geophysical data to geochemical analyses and mineral occurrences. These digital data sets form the basis for further use in a geographical information system and other computer-based interpretations. Provided that concessionary restrictions do not exist, GGU can supply the digital data to interested parties on an ad hoc basis and at cost. 


\section{Core Library}

At present, a total length of $73892 \mathrm{~m}$ of drill core, from 1047 drill holes, is available for inspection at GGU's headquarters in Copenhagen. The cores make up a representative collection of tested targets from both West and East Greenland (see Schønwandt, 1990). Figure 2 shows the locations in Greenland of the drill cores now in the library.

\section{Open File Series}

Eight reports dealing with economic mineral research were published in 1990 in GGU's Open File Series (Fig. 3). All reports summarise mineralisation data derived from both company reports and GGU files.

(1) Analyses of rock samples collected by GGU during reconnaissance for gold and base metals in the Archaean and Proterozoic supracrustal rocks of the Ivigtut-Kobberminebugt area, South-West Greenland are presented in table and map form by Erfurt \& Lind (1990). The highest gold value recorded is $5 \mathrm{ppm}$, and a discussion on mineralisation in the area concludes that the supracrustal rocks (greenstones and metasediments) have a potential for noble/base metal deposits.

(2) Results of reconnaissance and exploration work by several companies in the area between Arsuk Fjord and Neria, South-West Greenland have been compiled by Erfurt (1990). The rocks investigated comprise an Archaean greenstone belt and a suite of Proterozoic volcanic and sedimentary rocks. The investigations of the individual companies are described, and analyses of a variety of elements including $\mathrm{Au}$ are presented in tabular form. The highest gold value recorded is $19 \mathrm{ppm}$ over $2.5 \mathrm{~m}$ (chip sample). An assessment of the economic potential of the area is given and further exploration suggested.

(3) All major and several minor scheelite showings from the Nuuk region, southern West Greenland are summarised by Appel (1990a). A detailed description is presented of the most promising area where the best channel sample yielded $0.35 \%$ tungsten over $2.5 \mathrm{~m}$ from a mineralised zone traceable for more than $3.5 \mathrm{~km}$. Another zone which could be followed for $10 \mathrm{~km}$ returned up to $0.38 \%$ tungsten over $1.5 \mathrm{~m}$.

(4) Gold analyses from the early Archaean Isua supracrustal belt and from the mid-Archaean Malene supracrustal belt of southern West Greenland are presented by Appel (1990b). Silicate facies iron-formation of the Isua supracrustal rocks yield $1 \mathrm{ppm}$ gold, whereas other iron-formation facies return values of $0.1 \mathrm{ppm}$. In the Malene supracrustal rocks drill cores in a pyrite-rich

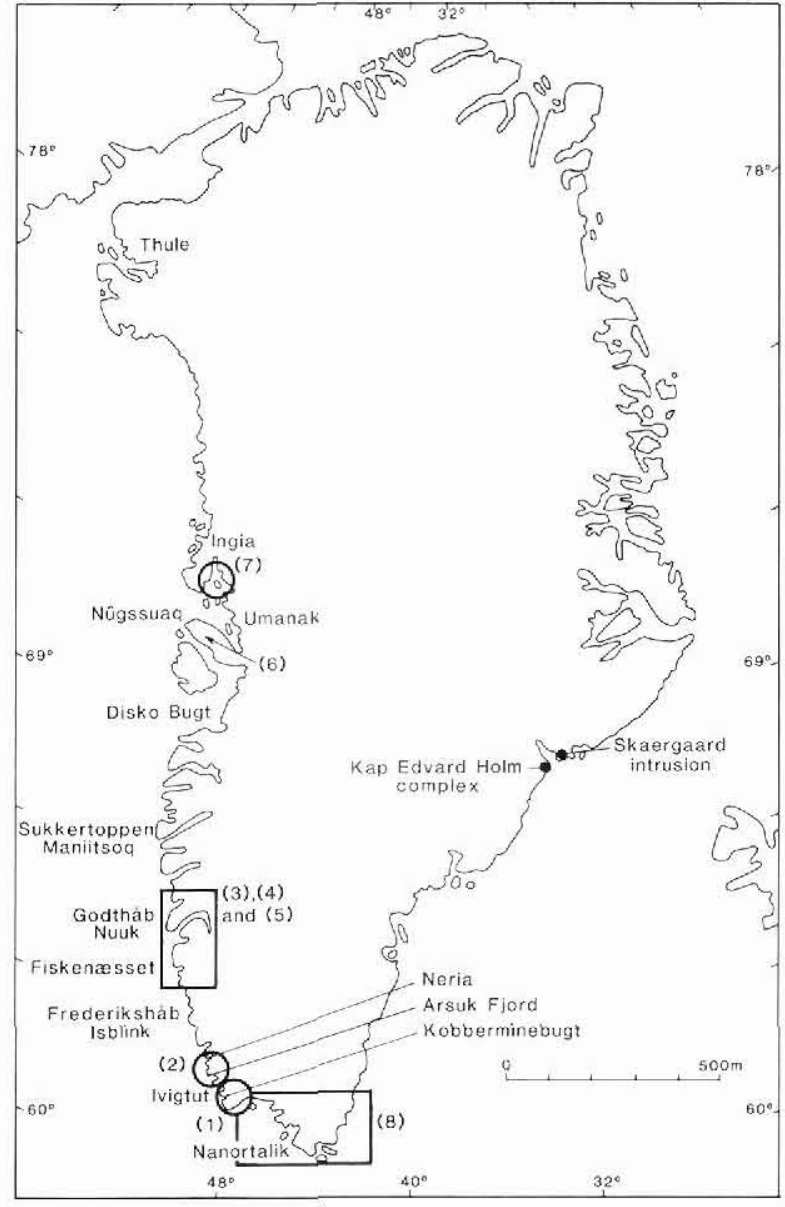

Fig. 3. Location map showing names mentioned in the text. Numbers in brackets refer to Open File reports discussed; circles and rectangles indicate the areas dealt with in the Open File reports.

zone traceable for many kilometres yielded $2.5 \mathrm{ppm} \mathrm{Au}$ over $0.2 \mathrm{~m}$. A few gold-bearing heavy-mineral concentrates are known from the southern part of the Nuuk area; however, no specific prospecting for gold has been carried out.

(5) Data on copper, zinc and nickel from the Nuuk region, southern West Greenland are summarised by Appel (1990c). The Malene supracrustal rocks display an assemblage dominated by mafic to ultramafic volcanic rocks often of komatiitic affinity. Thin sedimentary horizons of quartz-cordierite-sillimanite schists are also present, locally containing anthophyllite and tourmaline. The latter mineral locally forms tourmalinites composed of tourmaline and plagioclase with or without scheelite. Anthophyllite-rich bands up to several metres thick have been found in several places and consist of anthophyllite-gedrite, pyrrhotite, chalcopyrite, sphaler- 
ite, pyrite, molybdenite and gahnite. These horizons are interpreted as hydrothermal alteration zones, equivalent to those underlying massive copper-zinc sulphide bodies found elsewhere, e.g. western Ontario, Canada.

(6) The Archaean gneisses of central Nûgssuaq host a number of marble occurrences which probably belong to the Lower Proterozoic Marmorilik Formation. The largest marble occurrence is $c .150 \mathrm{~m}$ thick and exposed for $c .4 \mathrm{~km}$ along strike in a steep, 500-700 m high mountain cliff. Field work carried out in 1989 suggests that the marble forms a south-west facing recumbent isoclinal fold with a horizontal fold axis trending $c .135^{\circ}$. Horizons of massive sulphides, mainly sphalerite, are known from two localities within this marble occurrence. The mineralisation resembles the ore of the Black Angel mine situated some $80 \mathrm{~km}$ further northeast. A chip sample across a c. $1 \mathrm{~m}$ thick sulphide horizon returned $45 \% \mathrm{Zn}$ and $1 \% \mathrm{~Pb}$. The structural model presented here implies a potential for a significant zinc-lead deposit of the Black Angel type in central Nûgssuaq (Garde \& Thomassen, 1990).

(7) Thomassen (1990a) has presented data concerning stream and rock geochemistry from the Ingia area in the northern part of the Umanak district, central West Greenland. Several levels of stratiform pyrrhotite mineralisation occur in Lower Proterozoic supracrustal rocks. Although the sampled stratiform mineralisation only shows raised base metal contents, its presence suggests possibilities for economic metal concentrations and also constitutes a possible source rock for epigenetic mineralisation. Epigenetic quartz vein mineralisation, mainly known from boulders, has yielded gold contents of up to $371 \mathrm{ppb}$. A geochemical survey has outlined two anomalous areas characterised by goldarsenic-tungsten and gold-arsenic-cobalt. Pan samples returned up to $2.6 \mathrm{ppm}$ gold.

(8) A report presents the result of gold and arsenic analyses of $c .2200$ stream sediment samples from a regional survey covering South Greenland at a density of 1 sample per $2-5 \mathrm{~km}^{2}$. It is noteworthy that gold anomalies occur in both arsenic rich and arsenic poor environments, and this is taken to indicate the existence of at least two types of gold mineralisation. The report also contains a review of previous gold exploration activities in South Greenland (Steenfelt, 1990).

\section{Field investigations}

Field investigations focussing on economic mineral occurrences were undertaken in 1990 in two regions: North-East Greenland and central West Greenland (Fig. 3).

\section{North-East Greenland}

A geochemical and exploration reconnaissance programme was carried out in connection with the NorthEast Greenland project (see Henriksen, 1991). This work was a continuation of the geochemical programme initiated in 1989 and briefly described by Henriksen (1990). The geochemical survey corresponded to a sample density of approximately one sample per $30 \mathrm{~km}^{2}$. A total of 85 stream sediments and associated water samples were collected; 25 of these samples represented follow-up work in anomalous areas determined during the 1989 programme. In addition 22 panned heavy mineral concentrates were collected. The exploration reconnaissance recognised mineralisation in deformation zones and in alteration haloes around synkinematic to post-kinematic granites (Jensen \& Stendal, 1990).

\section{West Greenland}

In 1990 follow-up field work was carried out in the Ingia area of the Umanak district (Fig. 2) on two geochemical anomalies (Au-As-W and Au-As-Co) identified on the basis of the 1989 reconnaissance (Thomassen, 1990a). Detailed sampling of stream sediments was accomplished in the two areas and a semi-regional stream sediment and boulder sampling programme was carried out in the surrounding areas. A total of 58 stream sediments and panned heavy mineral concentrates, and 50 rock samples, were collected, and these will be analysed for 37 elements. Geochemical characterisation information combining results from 1989 and 1990 is planned for 1991.

The Ingia area consists of Archaean gneiss, the Lower Proterozoic supracrustal Karrat Group and Tertiary plateau basalts. In the investigated area the Karrat Group covers appoximately $1000 \mathrm{~km}^{2}$ which is about 10 per cent of the total extent of the Karrat Group in the Umanak district.

\section{References}

Appel, P. W. U. 1990a: Tungsten mineralization in the Nuuk region, West Greenland. Open File Ser. Grønlands geol. Unders. 90/4, $51 \mathrm{pp}$.

Appel, P. W. U. 1990b: Gold occurrences in supracrustal rocks of the Nuuk region, West Greenland. Open File Ser. Grønlands geol. Unders. 90/8, $21 \mathrm{pp}$.

Appel, P. W. U. 1990c: Copper, zinc and nickel occurrences in the Nuuk region, West Greenland. Open File Ser. Grønlands geol. Unders. 90/9, 28 pp.

Erfurt, P. 1990: Reconnaissance and exploration for gold and base metals in the area between Arsuk and Neria Fjords, 
South-West Greenland. Work performed 1971 to 1985: results and discussion. Open File Ser. Grønlands geol. Unders. 90/10, 85 pp.

Erfurt, P. \& Lind, M. 1990: Reconnaissance for noble and base metals in the Ivigtut-Kobberminebugt area, South Greenland: analytical results. Open File Ser. Grønlands geol. Unders. 90/7, $14 \mathrm{pp}$

Garde, A. A. \& Thomassen, B. 1990: Structural and economic aspects of the Proterozoic marble on Nûgssuaq, West Greenland. Open File Ser. Grønlands geol. Unders. 90/6, 14 pp.

Henriksen, N. 1990: Regional geology and 1:500 000 mapping in North-East Greenland. Rapp. Grønlands geol. Unders. 148, 16-20.

Henriksen, N. 1991: The North-East Greenland project 1988-90. Rapp. Grønlands geol. Unders. 152 (this volume).

Jensen, S. M. \& Stendal, H. 1990: Geochemical and ore geological field investigations in North-East Greenland $\left(76^{\circ}-\right.$ $78^{\circ} \mathrm{N}$ ). Express Report North-East Greenland 1990. Unpubl. intern. GGU rep., 49-55.

Nielsen, T. F. D. 1987: Tertiary alkaline magmatism in East Greenland: a review. In Fitton, J. G. \& Upton, B. G. J. (ed.) Alkaline igneous rocks. Spec. Publ. geol. Soc. Lond. 30, 489-515.

Schønwandt, H. K. 1990: Activities within the field of mineral resources. Rapp. Grønlands geol. Unders. 148, 37-40.

Steenfelt, A. 1990: Gold content of regional stream sediment samples from South Greenland. Open File Ser. Grønlands geol. Unders. 90/5, 12 pp.

Steenfelt, A., Thorning, L. \& Tukiainen, T. 1990: Regional compilations of geoscience data from the Nuuk-Maniitsoq region, southern West Greenland. Thematic Map Ser. Grønlands geol. Unders. 90/1, 57 maps.

Thomassen, B. 1990a: Prospecting for base and nobel metals in the Ingia area, West Greenland: analytical results. Open File Ser. Grønlands geol. Unders. 90/2, $61 \mathrm{pp.}$

Thomassen, B. 1990b: Delineation of targets for gold exploration: a case study from East Greenland. Chron. Rech. Min. $500,51-55$.

H. K. S., Geological Survey of Greenland, Copenhagen.

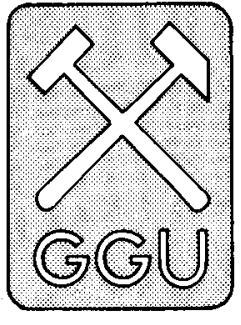

The Black Angel lead-zinc mine 1973-90

On 25th July 1990 the last ore was processed in the ore dressing plant at Mârmorilik thereby terminating seventeen years exploitation of the Black Angel (Sorte Engel) lead-zinc deposit (Fig. 1). During that period some 1.4 million tons zinc, 0.4 million tons lead and 250 tons silver have been extracted from the deposit which originally comprised 13.6 million tons ore grading $12.3 \% \mathrm{Zn}, 4.0 \% \mathrm{~Pb}, 29 \mathrm{ppm} \mathrm{Ag}$ and $13.7 \%$ Fe (Table 1). The mining operations ceased because the extractable ore reserves were exhausted.

Samples of lead-zinc sulphides that led to the discovery of the Black Angel deposit were found in connection with marble quarrying in the 1930s (Eklund, 1940) and investigated by Danish geologists in the 1930s and 1940s (Sølver, 1943; Pauly, 1952). Commercial investigations including diamond drilling ( 21 holes totalling 7.3 $\mathrm{km}$ ) were carried out in the 1960 s by a syndicate dominated by Cominco Ltd. of Canada. In 1971 the Danish mining company Greenex A/S (incorporated in 1964 and $62.5 \%$ owned by Cominco Ltd. through the subsidiary Vestgron Mines Ltd.) obtained an exploitation concession. Underground exploration in 1971-72 indicated a probable ore reserve of 4.1 million tons grading $15.0 \%$ $\mathrm{Zn}, 5.0 \% \mathrm{~Pb}$ and $28 \mathrm{ppm} \mathrm{Ag}$. Based on this reserve and after a hectic construction period, production started in October 1973. In July 1986 Greenex A/S was sold to the Swedish company Boliden Mineral AB.

\section{Geology}

The ores are hosted in the Mârmorilik Formation of the Lower Proterozoic Karrat Group (Garde, 1978; Henderson \& Pulvertaft, 1987). The formation rests unconformably on an Archaean gneiss complex and is overlain by semipelites of the upper Karrat Group. It consists of calcitic and dolomitic marbles with a basal quartzitic unit and intercalations of anhydrite-bearing marbles and semipelitic schists. The formation is be- 